\title{
Revisiting Quick Big Five Personality Test: Testing Measurement Invariance across Gender
}

\author{
Devrim ERDEM *
}

\begin{abstract}
Personality is a subject that has been studied because of the social, economic, individual, and educational implications of personality. The widely used model for measuring personality is the Five-Factor Model (FFM). The robustness of the factor structure of the FFM of personality has been provided among cultures and diverse samples. The measurement tools are used to identify differences between individuals or groups. However, in order to make meaningful comparisons, it is necessary to provide the measurement equivalence among the comparison groups. Thus the current study aimed to test the measurement invariance of the Quick Big Five $(\mathrm{QBF})$ items that are used in many disciplines in Turkey. For this purpose, the QBF items were investigated in terms of configural, metric, scalar and strict invariance across gender. In this research, 1114 university students aged between 17-32 years were included in the sample. Firstly, several CFAs were performed for the whole sample and then both men and women separately. The findings of the CFA revealed that the QBF model fit the data. In addition, each of the 30 items of the scale was embedded into a related latent factor in both gender groups. Secondly, sequential multiple group CFA tests to examine measurement invariance were conducted. According to the findings, full configural, partial metric and scalar invariance were fulfilled across gender. However, strict invariance could not be achieved. Imaginative and inquisitive under the openness factor were determined to cause measurement non-invariance. In conclusion, latent mean comparisons can be made by excluding these two items across gender.
\end{abstract}

Key Words: Five-factor model, personality traits, partial metric invariance, early adulthood, sex.

\section{INTRODUCTION}

Personality traits are comparatively long-lasting molds of opinions, emotions, and manners that make individuals different from each other (Bleidorn, Hopwood, \& Lucas, 2018). The development of personality traits throughout the life span has been an intriguing subject. Caspi and Shiner (2006) noted that one of the important reasons for this is that there are many theoretical and practical implications and outcomes of understanding personality development (cited in Morizot, 2014). Perhaps the most popular personality conceptualization used in personality measurement is the Five-Factor Model (FFM). This model arranges personality into five trait domains. However, this classification does not mean that all personality traits can be reduced into five factors; rather, the "big five" should be seen as broad but comprehensive factors based on a series of associated items (Mueller \& Plug, 2006; Paunonen \& Ashton, 2001). Almost universally, researchers have reached a consensus on the representation of the Five-Factor Personality Model (John, Neumann, \& Soto, 2008; Korkmaz, Somer, \& Gungor, 2013; McCrae, Terracciano, \& Pro, 2005).

The theoretical foundations of the Five-Factor Model (FFM) were formed by the lexical hypothesis (Allport \& Odbert, 1936 as cited in Poropat, 2009). According to this hypothesis, the most prominent features of people as personality traits eventually become part of their own language and show themselves in the language they use. Based on this hypothesis, it was envisioned that personality traits could be identified by looking at the descriptive adjectives in languages. Adjectives that may be indicative of personality, especially in English, have been determined. Afterwards, it was possible to develop scales based on Five-Factor Model and examines their validity with factor analytical studies in other languages (Saucier \& Goldberg, 1996).

\footnotetext{
* Assist. Prof., Niğde Ömer Halisdemir University, Faculty of Education, Niğde-Turkey, erdem_devrim@ yahoo.com, ORCID ID: 0000-0003-1810-2454
}

To cite this article:

Erdem, D. (2020). Revisiting quick big five personality test: Testing measurement invariance across gender. Journal of Measurement and Evaluation in Education and Psychology, 11(2), 180-198. doi: 10.21031/epod.675796 
The Big Five dimensions consist of agreeableness, extraversion, conscientiousness, neuroticism, and openness to experience. Individuals with a higher orientation in the Agreeableness dimension are known as compassionate, polite, tolerant, open to co-operation, and willing to help. Conscientiousness represents individual differences in target orientation, organized, self-discipline, impulse control, and compliance with social norms and rules. Individuals with a higher orientation in the Neuroticism dimension are considered worried, self-conscious, acting without forethought, and downbeat. They feel vulnerable, tend to experience low self-worth, and experience negative emotions relatively easily. Extraversion reflects being socially confident, willing to make friends, assertive and energetic. Individuals with a higher orientation in the Openness dimension are known as willing to try new things, broad-minded, intellectual curiosity, high imagination, creative, and artistic sensitivity (Barrick \& Mount, 1991).

It is noteworthy that most of the research on personality development focuses on early adulthood (Durbin et al., 2016; Fadjukoff, Feldt, Kokko, \& Pulkkinen, 2019; Johnson, Cohen, Brown, Smailes, \& Bernstein, 1999; Shiner, Allen, \& Masten, 2017; Soto, 2016). Longitudinal studies on the Big Five have shown that relatively great and resistant changes in personality have occurred in early adulthood (Roberts, Walton, \& Viechtbauer, 2006). This could be due to the fact that "important biological, social, and psychological changes occur throughout childhood and adolescence" (Soto, 2016, p. 410). Hence the period from late childhood through early adulthood is called a critical personality development period (Durbin et al., 2016). Besides, the frontal lobe of the brain continues to develop until the age of 25 or 28 . Further maturation of these regions of the brain enhances persons' capacity for better judgment, self-regulation, planned behaviors, and for more complex cognitive functioning. These functions do, in turn, contribute to the various developmental tasks of this age group. In addition, the period between the ages of 18 and 30 constitutes the transition to adulthood is an important stage of development in terms of sincerity, entrepreneurship, social interests, identity, work and parenting (Arnett, 2000). Indeed, research has shown that in early adulthood, interests are crystallized and balanced, and professional aspirations and prospects are delineated with more precision (Low \& Rounds, 2007). Therefore researchers still have an ongoing interest in this developmental period. Moreover, personality traits are part of the individual's productivity, and it is important to examine these traits as they are directly social and economic value.

\section{Gender Differences in Personality}

Personality traits are broad and relatively stable individual differences that affect human behavior and choices. Gender differences in personality traits have always been of interest to researchers (Kajonius \& Johnson, 2018). There are several reasons for this interest. First, gender differences in personality were observed in all cross-cultural studies (e.g., Costa, Terracciano, \& McCrae, 2001; Guimond, 2008; Schmitt, Realo, Voracek, \& Allik, 2008). It is a universal issue. Also, there is ample evidence that gender differences in personality are relatively stable throughout life (Donnellan, Conger, \& Burzette, 2007). In addition, many social choices such as occupational, educational, spousal selection, conflict, and relationship regulation are related to personality (Berings, De Fruyt, \& Bouwen, 2004; Bono, Boles, Judge, \& Lauver, 2002; Figueredo, Sefcek, \& Jones, 2006; Gasser, Larson, \& Borgen, 2007). For example, although there is an increase in women's level of education and participation in "highstatus professional fields, women and men are still concentrated in different occupations and educational programs, and women are still under-represented in the fields associated with physical science, engineering, and applied mathematics" (Eccles, 2011, p. 195). Unfortunately, there still exists a large gender aperture in mathematics, technology, engineering, and science majors (Cole \& Espinoza, 2008; Langen \& Dekkers, 2005; Legewie \& DiPrete, 2014; Wang \& Degol, 2017). Thus, it may be possible to monitor and improve the development of individuals, especially of women, in terms of education, skills and occupations by examining psychological factors such as personality traits, of course, along with various social policies toward gender equality.

Meta-analytic studies have shown that gender differences in psychological variables vary according to the construct examined. For example, men dominate sexual and physical aggression, status-seeking, and risk-taking behavior (Buss, 2004; Lynn, 1993). In contrast, devotion, care and benevolence 
tendencies are higher among women in all societies (Browne, 2006). The effect of personality on earnings (income) of women and men is also noteworthy. Compatibleness appears to be higher in women and lower in men and functions as a factor for women to consent to lower wages (Mueller \& Plug, 2006). Similarly, agreeableness and neuroticism consistently emerge as two traits that show the highest gender differences in women (Bouchard \& Loehlin, 2001; Costa et al., 2001; Kajonius \& Johnson, 2018). Self-identity and self-esteem are associated with sensitivity to others and focusing on relationships in women; in contrast, in men, it is associated with a tendency to establish autonomy and ascendancy over others (Josephs, Markus, \& Tafarodi, 1992). The FFM suggests that gender differences are usually small or moderate but significant, in terms of the effect size, and that men tend to show greater differences in personality traits than women (Borkenau, McCrae, \& Terracciano, 2013; Lippa, 2010).

On the other hand, the literature review shows that the last two decades has added a new perspective to the results of research on personality and gender. Surprisingly, more gender-based differences have been reported in more gender-egalitarian societies (Fischer \& Manstead, 2000; Kajonius \& Johnson, 2018; Schmitt, Long, McPhearson, O’Brien, Remmert, \& Shah, 2017). In other words, gender differences in personality are greater in more individual, more economically developed and more egalitarian societies, because this like of conditions lets men and women to more freely express their intrinsic dispositions (Falk \& Hermle, 2018). Therefore, such studies are crucial in order to grasp the origin of gender distinctions in personality traits and to broaden our understanding of this issue.

\section{Personality and Academic Performance}

Personality and its relations with social and economic structures have always been a lively research topic (Funder, 2001). On the other hand, the impact of personality on academic achievement and its educational implications have been ignored until the last decades. As Poropat (2014) pointed out that "One of the areas in which both educators and learners have been under-informed is the role of individual differences in learning and education, especially with respect to temperament and personality" (p. 24). Personality keeps a substantial role in students' school experience and academic success (Matthews, Zeidner, \& Roberts, 2006). The desire for performance in a job or academic activity and continuity in performance was found more decisive than FFM factors rather than mental ability (Heckman, Stixrud, \& Urzua, 2006, Judge \& Ilies, 2002; Willingham, Pollack, \& Lewis, 2002). Non-mental skills function a major role in the school performance of children and adolescents (Duckworth \& Seligman, 2005; Matthews et al., 2006). Some studies have shown that personality traits predict academic achievement better than indicators of cognitive measures (Lounsbury, Sundstrom, Loveland, \& Gibson, 2003).

Motivation, which has an important function in learning, is conceptualized as a personality trait (Rindermann \& Neubauer, 2001). Conscientiousness has been identified as the strongest dimension of FFM in predicting academic performance (Chamorro-Premuzic, \& Furnham, 2003; Dumfart \& Neubauer, 2016; Nguyen, Allen, \& Fraccastoro, 2005; O’Connor \& Paunonen, 2007; Poropat, 2009). Similarly Noftle and Robins (2007) pointed out Conscientiousness was the most powerful predictor of both high school and college GPA. Emotional stability (low neuroticism) is related to self-efficacy (Judge, Erez, Bono, \& Thoresen, 2002) and predicts academic achievement (Poropat, 2011). Noftle and Robins (2007) found Openness was the most potent predictor of SAT verbal scores. Openness to experience has been associated with learning, motivation for learning, intelligence, critical thinking, and lexical intellect (Bidjerano \& Dai, 2007; De Raad \& Schouwenburg, 1996; Klein \& Lee, 2006). Obviously, it is substantial to investigate the academic performance of individuals because significant investments are made in education by communities and individuals indicating the high worth given to educational performance (Poropat, 2009). The strong relationships between academic performance and Big Five personality factors indicate that we need to focus more on personality traits in terms of education. 


\section{Measurement Invariance on Big Five}

Empirical studies with different cultures and settings supported the robustness and generalizability of the Big Five personality factor structure (John \& Srivastava, 1999). In addition, there is considerable evidence that the Big Five personality traits have predictive validity in childhood, adolescence, and adulthood, as well as repeatability of factor structure during different developmental periods (see in Morizot, 2014). However, in order to interpret the differences or similarities between the comparison groups of a psychological construct, it is necessary to test the invariance of the psychological construct through measurement invariance. As mentioned so far, investigating personality traits is crucial to provide an understanding of educational decisions and developmental screening. Although there are significant differences between males and females, studies showing the equivalence of factor structures at the latent mean level are too limited in personality research (Morizot, 2014; Samuel, South, \& Griffin, 2015). Therefore, there is a need for research that supports the structure of the Big Five, which is widely used in almost every discipline (psychology, health, economy, education, sociology, etc.) with further validity analyzes. If the scalar measurement invariance can be achieved in comparison groups for Big Five construct, it is possible to make meaningful comparisons between the latent means (Ock, McAbee, Mulfinger, \& Oswald, 2020; Sass, 2011). Otherwise, it cannot be determined whether the resulting differences can actually be attributed to the true difference between the groups or to a situation stemming from the lack of equivalence of the psychological construct. In this case, both the validity and generalizability of the psychological structure become problematic.

While several Turkish instruments have been developed based on the Big Five theory, they are often too long for practical applications. Also, the measurement invariance of such scales has not been studied. Only Korkmaz et al. (2013) examined the measurement invariance of gender in high school adolescents on a 200 -item scale developed by them. However, further research is needed with various developmental groups. In behavioral sciences, researchers tend to view scales that are above 40 items as "substantial length" and generally prefer "abridged" versions (Roets \& Van Hiel, 2011). Since the Quick Big Five (QBF) scale is a relatively "brief" scale, it provides ease of use and application. Indeed, this is why it has been preferred in many research and used widely by professionals from various disciplines (education, health, economics, psychology, etc.). Understanding the development of personality traits throughout life span has theoretical and practical consequences (Roberts, Kuncel, Shiner, Caspi, \& Goldberg, 2007). In particular, it is important to examine the validity of the scores obtained from relatively shorter self-report tools through further studies. Such studies are also important in contributing to current discussions about the nature of the personality and in terms of understanding cultural differences in personality factors. Only with such an evidence, the use of the current instrument in university-counseling centers for clinical use or for the use of researchers intending to make gender comparisons could yield to sound results. Therefore, the current study has two aims: (1) to test model fit of the Quick Big Five (QBF) on a Turkish early adulthood sample, and (2) to test the measurement invariance of the scale items. Concerning the second purpose, QBF-30 items under five factors were examined in terms of configural, metric, scalar and strict invariance across gender.

\section{METHOD}

This study aimed at investigating measurement invariance of the Quick Big Five scale across gender. In this section the participants, data collection tool, and the data analysis were described.

\section{Participants}

The sample was comprised of 1114 university students, aged $17-32$ years $\left(M_{\text {age }}=20.8\right.$, Median $_{\text {age }}=$ $21, S D=2.4)$, from Central-Anatolia Turkey. Among them were 659 females (59\%) and 455 males (41\%). Information on students' faculty and grade were presented in the Table 1. Data were collected during the 2018-2019 academic year. 
Table 1. Participants' Faculty and Grade

\begin{tabular}{llrr}
\hline & $\boldsymbol{f}$ & $\boldsymbol{\%}$ \\
\hline Faculty & Missing & 26 & 2.3 \\
& Education & 270 & 24.2 \\
& Science and Literature & 121 & 10.9 \\
& Economics and Administrative Sciences & 236 & 21.2 \\
& Engineering & 201 & 18.0 \\
Architecture & 62 & 5.6 \\
& Communication & 47 & 4.2 \\
& Agricultural Sciences and Technologies & 71 & 6.4 \\
& Islamic Sciences & 40 & 3.6 \\
& Medicine & 40 & 3.6 \\
\hline Total & 1114 & 100.0 \\
\hline Preparatory & 44 & 3.9 \\
& $1^{\text {st }}$ & 219 & 19.7 \\
$2^{\text {nd }}$ & 242 & 21.7 \\
3 $^{\text {rd }}$ & $4^{\text {th }}$ & 419 & 37.6 \\
& Total & 190 & 17.1 \\
\hline
\end{tabular}

\section{Data Collection Instrument}

The QBF is a scale measuring personality traits. The QBF was adapted from Goldberg's Big Five Personality scale consisting of 100 adjectives by reducing the number of items to 30 (Vermulst \& Gerris, 2005). There were two groups in their study. There were 12107 participants (5865 male) in the 12-18 age group and 7172 participants (3622 male) in the 19 and older age group. The QBF personality dimensions are extraversion, conscientiousness, agreeableness, emotional stability, and openness. Each personality trait is measured with six items; thus, the scale consists of 30 items. The items are marked on a 7-grade rating scale that ranges from completely untrue (1 point) to completely true (7 points). The 12 items in the scale are reverse coded. The scores for each subscale range from 6 to 42 . High scores indicate high levels of the relevant personality dimension. Confirmatory factor analysis (CFA) was used to determine the factor structure of the scale. CFA results showed that the 5-factor structure was confirmed (RMSEA $=.05, \mathrm{CFI}=.96$ ). The Cronbach Alpha values for the sub-scales were .81 for extraversion, .80 for agreeableness, .86 for conscientiousness, .78 for emotional stability and .73 for openness to experience respectively. The test-retest reliability of the scale was also acceptable (Vermulst \& Gerris, 2005). The validity studies of the QBF have been conducted in different adolescent and adult groups until now (e.g., Borghuis et al., 2017; Klimstra et al., 2013; Manders, Scholte, Janssens, \& De Bruyn, 2006).

The QBF was adapted to Turkish culture by Morsunbul (2014). In his study, 793 participants were included consisting of two age groups: adolescent group aged 14-17 and university students aged 1822. Based on the CFA results $\left(\chi^{2} / d f=3.76, \mathrm{GFI}=.91, \mathrm{CFI}=.92, \mathrm{NFI}=.91, \mathrm{NNFI}=.91 \mathrm{RMSEA}=\right.$ .08 ), the five-factor structure of the scale was confirmed with the Turkish sample. The Cronbach's Alpha coefficients of the subscales ranged from .71 to .81 in the adaptation study.

Before completing the QBF, participants were asked for gender, age, grade and faculty information. Informed consent was obtained from all participants involved in the study. Data for this study was collected during the academic year of 2018-2019. Although at the time of data collection the institutional ethical permission was not obtained, all necessary steps were taken to ensure the ethical rights of the participants. The nature of questions/items on the surveys was not of any sort to pose any likely distress for participating students. Nor the results of the study pose any risk for bridging of confidentiality. Thus, during data collection, in reporting the findings as well as by not obtaining or revealing students' names or other personal information, the study adhered to ethical principles at the utmost level. 


\section{Data Analysis}

The suitability of the data for the analyses was examined before proceeding to the analyses. Data entry, missing value, outlier, and normality were evaluated with SPSS 22.0. LISREL9.2 was used for the confirmatory factor analysis (CFA) and multiple-group CFA for testing invariance across gender.

\section{Confirmatory factor analysis}

Confirmatory factor analysis (CFA) was performed to examine the model fit. The maximum likelihood estimation method with the covariance matrix was employed in the CFA. Because the chi-square $\left(\chi^{2}\right)$ statistic is sensitive to sample size, it may cause inflated chi-square values (Kline, 2011). Therefore, various fit indexes were also evaluated along with the chi-square statistic. The following criteria and indices recommended by Hu and Bentler (1999) and Kline (2011) were taken into consideration. The comparative fit index (CFI), which is less sensitive to large samples and the non-normed fit index (NNFI), which is generally considered to be relatively independent of sample size were preferred as incremental fit indexes. The goodness of fit index (GFI) and the root-mean-square error of approximation (RMSEA) were chosen as absolute fit indexes considered while assessing model fit in CFA. While "an absolute-fit index directly assesses how well an a priori model reproduces the sample data" (Hu \& Bentler, 1998, p.426) "incremental fit indexes evaluate model fit by comparing a target model with a more restricted, nested baseline model" (Beauducel \& Wittmann, 2005, p.45). The ratio of chi-square to degrees of freedom $\left(\chi^{2} / d f\right)$ values less than 5 suggest sufficient fit; the CFI, GFI, and NNFI values .90 or greater indicate adequate model fit. The RMSEA values .08 or less point out a good fit.

\section{Measurement invariance}

Measurement invariance has been viewed as a way of assessing the applicability of test instruments when the same psychological construct is intended to be measured in a different group (Cheung \& Rensvold, 2002). In this study, measurement invariance was tested by multiple groups confirmatory factor analysis (MGCFA). A series of successive tests are followed for the measurement invariance. First, the configural model is tested. When testing the configural invariance, factor loadings and intercepts are not restricted, except for reference indicators, and factor means are fixed at 0 for both groups (Putnick \& Bornstein, 2016). Ensuring the configural invariance is a prerequisite for the metric, scalar, and strict invariance. After establishing the configural invariance, metric invariance is tested. When testing the metric invariance, the factor loadings are equalized, but intercepts are not restricted between the groups (Putnick \& Bornstein, 2016). After achieving the metric invariance, scalar invariance is tested. When testing scalar invariance, factor loadings and intercepts are restricted, but error variances were allowed to vary across groups. If scalar invariance is obtained, then strict invariance is tested. When testing strict invariance (invariant uniqueness), all error variances are constrained to be equal across groups (Milfont \& Fischer, 2010).

Chi-square difference test $\left(\Delta \chi^{2}\right)$ is employed to compare these nested models (Brown, 2006; Dimitrov, 2010; Tabachnick \& Fidell, 2001). The presence of a non-significant difference for each model indicates that the measurement invariance is accepted. However, if it is considered that the chi-square test is affected by the sample size, it is recommended to use another indicator. Therefore, following to recommendation of Cheung and Rensvold (2002) CFIs difference values ( $\Delta \mathrm{CFI}$ ) were used to compare these nested models. In order to accept measurement invariance, the delta CFI value in each model tested must be greater than -0.01 (Cheung \& Rensvold, 2002). When measurement invariance cannot be achieved, partial measurement invariance is examined. As Milfont and Fischer (2010) stated "partial measurement invariance may allow appropriate cross-group comparisons even if full measurement invariance is not obtained." (p.117).

According to Van De Schoot, Lugtig, and Hox (2012), the purpose of analyzing partial measurement invariance is to determine which loadings or intercepts differ between groups. The authors suggested following the steps to establish partial measurement invariance: 
Study the size of the loadings and/or intercepts, and constrain all loadings and intercepts, except for the one loading/intercept with the largest unstandardized difference, which is released. Subsequently, compare this new model with the old Model 1 or 2. If $\Delta \chi^{2}$ is now insignificant, partial invariance is established. If $\Delta \chi^{2}$ is still significant release another item, and continue until the item that causes MI not to hold is identified. (p.491)

In line with the recommendations of these researchers, the suitability of individual parameter equality constraints was examined when it is necessary to investigate the partial invariance. In this current study, while checking partial invariance $\Delta$ CFI value along with $\Delta \chi^{2}$ was taken into consideration.

\section{RESULTS}

\section{Confirmatory Factor Analysis}

A CFA was conducted to investigate the model fit to the Quick Big Five scale. The fit indexes for the five-factor structure with 30 items were found for the full sample as follows (in Table 2): $\chi^{2}{ }_{(395)}=$ $4457.75(p<.000)$ and $\chi^{2} / d f=11.28$ did not support the fit of the model. As already mentioned, this was an expected finding related to the sensitivity to the sample size of the chi-square statistics. The other fit indexes were found as follows: $\mathrm{CFI}=.94$, NNFI $=.94$, GFI $=.93$ and RMSEA $=.082[90 \%$ lower-upper confidence interval .080 - .085]. The RMSEA deviated slightly from model fit. On the other hand, based on the values concerning CFI, NNFI, and GFI, the model-data fit was met. According to the $t$-test, factor loadings in CFA were found significant at .05 level. In light of these findings, it was concluded that the model data fit for the five-factor solution of the scale was acceptable.

\section{Measurement Invariance Across Gender}

In order to examine the measurement invariance according to gender, firstly CFA was performed separately in female and male groups. According to the $\chi^{2} / d f$, model fit was not attained for both the female and the male groups. However considering the alternative fit indices it was concluded that the model fit was acceptable for the female as well as the male groups based on the CFI, NNFI, and GFI values. On the other hand, RMSEA values both females and males indicated a bit model misfit. These findings presented in Table 2 .

Table 2. Goodness-of-fit Indexes for the Full Sample and the Baseline Model across Gender

\begin{tabular}{|c|c|c|c|c|c|c|c|c|c|}
\hline \multirow[t]{2}{*}{ Group } & \multirow{2}{*}{$\chi^{2}$} & \multirow[b]{2}{*}{$d f$} & \multirow{2}{*}{$\chi^{2} / d f$} & \multirow{2}{*}{ CFI } & \multirow{2}{*}{ NNFI } & \multirow[b]{2}{*}{ GFI } & \multirow[b]{2}{*}{ RMSEA } & \multicolumn{2}{|c|}{$90 \%$ CI for RMSEA } \\
\hline & & & & & & & & Lower & Upper \\
\hline Full & $4457.75 * * *$ & 395 & 11.28 & .94 & .94 & .93 & .08 & .080 & .085 \\
\hline Female & $2526.20 * * *$ & 395 & 6.4 & .93 & .93 & .90 & .09 & .088 & .092 \\
\hline Male & $1978.81 * * *$ & 395 & 5.0 & .95 & .95 & .93 & .09 & .089 & .095 \\
\hline
\end{tabular}

After the baseline model was achieved the next step was to establish configural invariance. Although conducting individual CFAs in each group (baseline models) can test configural invariance, it is still necessary to run this step in MGCFA (Milfont \& Fischer, 2010). Configural model presented at Table 4 showed adequate fit to the data, except for the chi-square statistics $\left(\chi^{2} / d f=6.61, \mathrm{CFI}=.93, \mathrm{NNFI}=\right.$ .92 , RMSEA $=.08$ ). These findings indicated that the factorial structure of the construct was equal across gender. Standardized factor loadings, error terms and $t$-values in the baseline (configural) model were presented in Table 3.

Next, metric invariance was examined. Findings of the fit indexes of measurement invariance were presented in Table 4 . While comparing nested models, the chi-square difference test and $\Delta C F I$ values were examined. The chi-square difference between metric model and configural model was 
statistically significant $\left(\Delta \chi_{(30)}^{2}=1820.59, p<.0001\right)$ and $\Delta \mathrm{CFI}=-.03<-.01$; thus indicating metric invariance was not achieved. These findings showed that factor loadings could not be accepted as equal across gender groups.

Table 3. Standardized Factor Loadings, Error Terms and t-values in the Configural Model

\begin{tabular}{|c|c|c|c|c|c|c|c|}
\hline \multicolumn{2}{|c|}{ Items } & \multicolumn{2}{|c|}{$\begin{array}{c}\text { Standardized factor } \\
\text { loadings }\end{array}$} & \multicolumn{2}{|c|}{ Standard Error } & \multicolumn{2}{|c|}{$t$-values } \\
\hline \multirow{2}{*}{\multicolumn{8}{|c|}{ Agreeableness }} \\
\hline & & & & & & & \\
\hline 5 & Pleasant & .55 & .69 & .059 & .072 & 15.73 & 16.21 \\
\hline 10 & Helpful & .60 & .68 & .060 & .072 & 17.03 & 16.21 \\
\hline 15 & Kind & .72 & .73 & .056 & .066 & 21.36 & 18.66 \\
\hline 20 & Cooperative & .51 & .57 & .072 & .086 & 14.01 & 13.24 \\
\hline 22 & Agreeable & .64 & .66 & .064 & .075 & 18.21 & 15.99 \\
\hline 28 & Sympathetic & .67 & .66 & .063 & .073 & 19.35 & 16.35 \\
\hline \multicolumn{8}{|c|}{ Extraversion } \\
\hline 4 & Reserved $^{R}$ & .44 & .62 & .071 & .087 & 12.02 & 13.54 \\
\hline 9 & Quiet $^{R}$ & .60 & .62 & .073 & .086 & 16.61 & 14.46 \\
\hline 13 & Introverted $^{R}$ & .65 & .73 & .070 & .085 & 18.84 & 17.55 \\
\hline 18 & Talkative & .23 & .37 & .077 & .092 & -5.90 & -7.74 \\
\hline 21 & Bashful $^{R}$ & .73 & .75 & .072 & .085 & 21.42 & 18.65 \\
\hline 26 & Withdrawn $^{R}$ & .75 & .71 & .073 & .084 & 21.66 & 17.87 \\
\hline \multicolumn{8}{|c|}{ Conscientiousness } \\
\hline 3 & Sloppy $^{R}$ & .18 & -.07 & .084 & .097 & 4.35 & 2.50 \\
\hline 8 & Careful & .57 & -.64 & .067 & .080 & 15.47 & -14.64 \\
\hline 12 & Organized & .76 & -.86 & .065 & .080 & 23.37 & -21.55 \\
\hline 17 & Prompt & .56 & -.65 & .074 & .089 & 15.39 & -14.83 \\
\hline 25 & Neat & .74 & -.82 & .071 & .086 & 22.33 & -20.41 \\
\hline 27 & Systematic & .63 & -.73 & .070 & .086 & 17.96 & -17.18 \\
\hline \multicolumn{8}{|c|}{ Neuroticism } \\
\hline 2 & Irritable $^{R}$ & .39 & .46 & .077 & .092 & 10.14 & 9.87 \\
\hline 7 & High-strung $^{R}$ & .58 & .62 & .068 & .082 & 16.01 & 14.21 \\
\hline 11 & Touchy $^{R}$ & .59 & .56 & .074 & .087 & 16.03 & 13.02 \\
\hline 16 & Anxious $^{R}$ & .74 & .72 & .068 & .079 & 21.72 & 18.03 \\
\hline 24 & Fearful $^{R}$ & .62 & .49 & .077 & .088 & 16.59 & 11.42 \\
\hline 29 & Nervous $^{R}$ & .73 & .69 & .070 & .082 & 21.05 & 17.03 \\
\hline \multicolumn{8}{|c|}{ Openness } \\
\hline 1 & Imaginative* & .58 & .86 & .056 & .070 & 18.29 & 20.47 \\
\hline 6 & Inquisitive* $^{*}$ & .61 & .84 & .063 & .074 & 18.39 & 20.43 \\
\hline 14 & Sophisticated & .67 & .81 & .056 & .070 & 20.31 & 19.99 \\
\hline 19 & Innovative & .68 & .80 & .064 & .076 & 20.36 & 20.04 \\
\hline 23 & Artistic & .57 & .56 & .078 & .093 & 15.67 & 13.11 \\
\hline 30 & Creative & .72 & .80 & .064 & .075 & 21.73 & 20.57 \\
\hline
\end{tabular}

Partial metric invariance was investigated in order to determine which item or item groups had different factor loadings. When full metric invariance is not attained, the non-invariant items can be found by gradually releasing the factor loadings according to items with the highest modification index until a final partial metric invariance model is achieved (Cooper, Gomez, \& Aucote, 2007). Following the recommendation, item 1 (imaginative) was determined as having the highest modification index. In addition, the factor loadings of item 1 in females and males yielded the highest difference (as shown in Table 3). Vandenberg (2002) stated, "after accurately identifying the items that are not invariant, the researcher engages in a partial metric invariance strategy whereby the non-invariant items are freely estimated in each group, but the invariant items are fixed equal between groups" (p. 151). In light of this suggestion, item 1 was freely estimated in both groups, and then still, a statistically significant difference between this model and configural model $(p<.001)$ was observed. The $\Delta$ CFI $(-$ .03 ) value also indicated that the model fit could not be established. Ongoing examination of the item with the highest modification index in the last model was determined as item 6 (inquisitive). In addition, the factor loadings of item 6 in females and males yielded the second-highest difference (as shown in Table 3). When item 1 and item 6 were freely estimated in both groups, an insignificant 
difference between this model and configural model $(p=.012)$ at .01 level was found. The $\Delta$ CFI value (0.0) lower than -.01 also indicated that the model fit was supported. That is, partial metric invariance was established across the groups, except for the factor loadings of item 1 and item 6.

Table 4. Fit Indexes for Measurement Invariance Models across Gender

\begin{tabular}{lrrrrrrrrr}
\hline Model & $\chi^{2}$ & $d f$ & CFI & NNFI & RMSEA & $\Delta \chi^{2}$ & $\Delta d f$ & $p$ & $\Delta$ CFI \\
\hline Configural & 5426.42 & 820 & .93 & .92 & .08 & - & - & - & - \\
Metric & 7247.01 & 850 & .90 & .90 & .13 & 1820.59 & 30 & .000 & $\mathbf{- . 0 3}$ \\
Partial Metric - I1 & 5704.39 & 827 & .92 & .91 & .09 & 277.97 & 7 & .000 & -.01 \\
Partial Metric - I1 \& I6 & 5442.77 & 826 & .93 & .93 & .09 & 16.35 & 6 & .012 & 0.0 \\
Scalar & 5456.86 & 831 & .93 & .93 & .09 & 14.09 & 5 & .015 & 0.0 \\
Strict & 7286.46 & 802 & .89 & .89 & .14 & 1829.6 & 29 & .000 & $\mathbf{- . 0 4}$ \\
\hline
\end{tabular}

After partial metric invariance was established, the scalar invariance test was conducted. The findings were indicated that the chi-square difference between the scalar model and the partial metric model was not statistically significant $\left(\Delta \chi^{2}{ }_{(5)}=14.09, p>.01\right)$. The zero $\Delta$ CFI value higher than -.01 indicated scalar invariance. After achieving scalar invariance, in order to examine the highest level of measurement invariance with the test of invariance of error variance was carried on. The chi-square difference between the strict model and the scalar model was statistically significant $\left(\Delta \chi_{(29)}^{2}=1829.6\right.$, $p<.001$ ) and the $\Delta \mathrm{CFI}=-.04$ is lower than -.01 . These findings showed that strict invariance was not achieved.

\section{DISCUSSION and CONCLUSION}

The aim of the study was twofold. The first purpose of the present study was to test the factorial validity of the Quick Big Five on the Turkish early adulthood sample, and the second was to examine measurement invariance across gender. Firstly, CFA was performed for the whole sample. Afterwards, the model fit was evaluated separately for both male and female groups. Secondly, sequential multiple group CFA tests to examine measurement invariance were conducted.

In general, most of the fit indexes emerged that the Quick Big Five showed adequate fit to the data for the whole sample and the gender groups. However, RMSEA and $\chi^{2} / d f$ indicated model misfits. Since the chi-square statistic is sensitive to model size (e.g., the number of observed variables and factors estimated, model degrees of freedom) and sample size (Putnick \& Bornstein, 2016), it is not surprising that chi-square showed model misfit. These findings are in line with the findings related to personality traits in the literature. For instance, Beauducel and Wittmann (2005) examined the performance of CFA fit indexes in their simulation study. The simulated data in their study were set as characteristic of data in personality research. As a result of their research, the researchers stated that "there is a tendency to indicate misfit for RMSEA and $\chi^{2} / d f$ values when the incremental fit indexes indicate fit." (p.57). They also revealed the situation regarding model fit in personality research as follows:

According to Raykov (1998), a perfect model fit is not very realistic in personality research because the personality phenomenon can be considered exceedingly complex and because it is not possible to include all relevant variables in studies on personality. When the models do not contain all relevant variables, it is very unlikely that they will explain all relevant aspects of an empirical covariance matrix. Thus, a problem that is emphasized when the application of CFA to personality research is discussed is the extreme complexity of the phenomena under investigation. (Beauducel \& Wittmann, 2005, p.42).

As researchers pointed out, it is obvious that there are some problems in model-data fit concerning personality research. The current research findings also are consistent with the literature.

Based on the findings, full configural, partial metric, and scalar invariance were achieved across gender. The fact that configural invariance has been achieved indicates that the Quick Big Five Scale 
has a comparable factor structure between females and males. Configural invariance is a prerequisite and should be established in order for subsequent tests to be consequential (Vandenberg \& Lance, 2000). In the subsequent test, findings failed to support full metric invariance. However, if latent constructs are to be meaningful in a comparison between groups, equal factor loadings must first be obtained (Cheung \& Rensvold, 2002). Therefore, after investigating modification indices, the two items found as non-invariant across the groups. Model fit was acceptable after freeing the factor loadings for item 1 and item 6. The two non-invariant items were "imaginative" and "inquisitive". Both of the items were under the same dimension entitled Openness. Males had higher factor loadings on both non-invariant items which implies that these items are more strongly associated with the scale of the Quick Big Five in males than in females. In other words, these two statements have a different meaning and/or interpretation for the males and the females. This finding is understandable given the patriarchal cultural context of Turkey, and individuals are at the onset of their lives meticulously socialized into highly rigid gender roles where males are encouraged to explore their environments and be independent while female behaviors are closely controlled and monitored so as to promote a strictly rule-abiding lifestyle. Therefore, boys are encouraged and praised for their curiosity and bravery in an exploration of their environment and accumulation of life skills while girls are particularly in the name of "sexual protection" are discouraged toward such exploration whether that be actual or imaginary. In short, males and females are given extremely different sets of rules regarding experimentation with new experiences.

After partial metric invariance was fulfilled, the scalar invariance was tested. The findings showed that item intercepts (except for item 1 and item 6 ) were invariant across the gender groups. These findings are partly consistent with the findings of the study conducted by Morizot (2014) on an adolescent sample. Morizot (2014) reported that partial scalar (intercept) invariance was achieved when four items were released in the Big Five Personality Trait Short Questionnaire (BFPTSQ). Two of these non-invariance items were artistic-related items that were from the Openness. As mentioned above, in the present study two items of Openness caused metric non-invariance. In accordance with the current literature, the items on Openness had the lowest fit for the FFM data (Rollock \& Lui, 2016). There appear some difficulties in understanding the concept of Openness (McCrae \& Costa, 1997). Openness is quite hard to define clearly (DeYoung, Peterson, \& Higgins, 2005). This may be due to the fact that the abstract and complex definition of Openness (Connelly, Ones, Davies, \& Birkland, 2014). Openness includes motivation, needs to reach out novel and varied experience, but sometimes proposes clearly improper receptivity (McCrae \& Costa, 1997). Openness to Experience also requires vision, aesthetic sensitivity, and is willing to discard the thought of traditional values. Thus, the dimension of Openness is perhaps not a core concept of personality universally but may have specific meanings in cultural contexts. So much so that the Openness factor did not emerge in the original Chinese Personality Assessment Inventory (Cheung et al., 2008). This was because the FFM model, which was built on the conceptualization of Western-centered personality, did not fit into the more collective Eastern culture (Cheung, Fan, \& To, 2008). Triandis and Suh (2002) stated, "The Openness factor is problematic in several studies" and added "Openness emerges more readily in individualist cultures, particularly among student samples that tend to be idiocentric, than in collectivist cultures" (p. 150). There are also views that culture has different levels of influence, even in a single psychological domain such as personality (McAdams \& Pals, 2006). McCrae, Yik, Trapnell, Bond, and Paulhus (1998) stated that the cross-lingual equivalence of the scale of Openness was quite limited but still this result was not amazing because it measures the "attitudinal reflections" of the relevant areas of the scale "and attitudes are undoubtedly influenced by the cultural context" (p. 1052).

The highest level of measurement invariance is strict invariance. In the current study the strict invariance was tested but not achieved. This finding was in line with the study done by Samuel et al. (2015) in which they demonstrated full configural, metric, and scalar invariance but did not achieve strict invariance on The Five-Factor Model Rating Form across gender. On the other hand, in the literature, it is noted that strict invariance is a very restricted test; thus, it is not compulsory to compare latent mean differences (Brown, 2006).

In conclusion, the findings of the CFA confirmed the Quick Big Five (five-factor) adequately fit the data from the Turkish early adulthood sample. In addition, each of the 30 items of the scale was 
embedded into a related latent factor in both gender groups. This study resulted in several important outcomes. The first important outcome of this study is that the QBF scale operates in Turkish early adulthood sample. Further, the QBF scale was able to carry on full configural, partial metric and scalar invariance between males and females. That is, the QBF scores have the same measurement unit and origin across gender groups when the item 1 and item 6 are excluded. Therefore, the equivalence evidence of the QBF scale of a Turkish sample was built on across gender groups. In other words, meaningful comparisons can be made between the latent mean of the construct.

Even within a nation itself, differences in response manner or expression of personality traits can be shaped depending on cultural contexts (Rollock \& Lui, 2016). Therefore, in future research, evidence of validity for diverse groups can be investigated. Likewise, the measurement invariance of the distinct comparison groups can be examined. Because, while examining personality traits, it provides more insight into similarities and differences in item-based studies rather than domains or factors. In addition, there is a need for comprehensive studies on whether the Openness dimension and the facets under this dimension are an etic (universally) or an emic (culture-based) construct. Besides, inconsistency was observed between the CFA fit indices in this study. Therefore, further research on the behavior of different fit indices could be conducted in personality research.

Because personality traits are closely associated with academic variables, educators who intend to enhance individuals' academic performance should have a keen interest in personality. The findings of this study indicated that the QBF is a valid self-report tool that can be easily applied for the early adulthood period in Turkish culture. Thus, the QBF can be used to enhance academic achievement as well as tailoring of teaching methods and techniques to the individual in school settings. Likewise, it can be used at least in addition to other instruments in employee selection in a variety of human resources and occupational guidance settings. In addition, the QBF scores can guide educational and vocational counselors to provide more functional guidance for clients. This research includes some theoretical implications. It confirmed that making group comparisons without taking into account the items where measurement invariance cannot be achieved would lead to biased decisions. It also added new validity evidence to existing personality literature.

\section{REFERENCES}

Arnett, J. J. (2000). Emerging adulthood: A theory of development from the late teens through the twenties. American Psychologist, 55(5), 469-480. doi: 10.1037//0003-066X.55.5.469

Barrick, M. R., \& Mount, M. K. (1991). The big five personality dimensions and job performance: A metaanalysis. Personnel Psychology, 44(1), 1-26. Retrieved from http://jwalkonline.org/docs/Grad\%20Classes/Fall\%2007/Org\%20Psy/big\%205\%20and\%20job\%20per f.pdf

Beauducel, A., \& Wittmann, W. W. (2005). Simulation study on fit indexes in CFA based on data with slightly distorted simple structure. Structural Equation Modeling, 12(1), 41-75. doi: $10.1207 /$ s15328007sem1201_3

Berings, D., De Fruyt, F., \& Bouwen, R. (2004). Work values and personality traits as predictors of enterprising and social vocational interests. Personality and Individual Differences, 36(2), 349-364. doi: 10.1016/s0191-8869(03)00101-6

Bidjerano, T., \& Dai, D. Y. (2007). The relationship between the big-five model of personality and self-regulated learning strategies. Learning and individual differences, 17(1), 69-81. doi: 10.1016/j.lindif.2007.02.001

Bleidorn, W., Hopwood, C. J., \& Lucas, R. E. (2018). Life events and personality trait change. Journal of Personality, 86(1), 83-96. doi: 10.1111/jopy.12286

Bono, J. E., Boles, T. L., Judge, T. A., \& Lauver, K. J. (2002). The role of personality in task and relationship conflict. Journal of Personality, 70(3), 311-344. doi: 10.1111/1467-6494.05007

Borghuis, J., Denissen, J. J., Oberski, D., Sijtsma, K., Meeus, W. H., Branje, S., ..., \& Bleidorn, W. (2017). Big Five personality stability, change, and codevelopment across adolescence and early adulthood. Journal of Personality and Social Psychology, 113(4), 641-657. doi: 10.1037/pspp0000138

Borkenau, P., McCrae, R. R., \& Terracciano, A. (2013). Do men vary more than women in personality? A study in 51 cultures. Journal of Research in Personality, 47(2), 135-144. doi: 10.1016/j.jrp.2012.12.001

Bouchard, T. J., \& Loehlin, J. C. (2001). Genes, evolution, and personality. Behavior Genetics, 31(3), $243-273$. doi: 10.1023/A:1012294324713 
Brown, T. A. (2006). Confirmatory factor analysis for applied research. New York, NY: Guilford Press.

Browne, K. R. (2006). Evolved sex differences and occupational segregation. Journal of Organizational Behavior, 27(2), 143-162. doi: 10.1002/job.349

Buss, D. M. (2004). Evolutionary psychology: The new science of the mind (2nd ed.). Boston, MA: Allyn \& Bacon.

Chamorro-Premuzic, T., \& Furnham, A. (2003). Personality predicts academic performance: Evidence from two longitudinal university samples. Journal of Research in Personality, 37(4), 319-338. doi: 10.1016/S0092-6566(02)00578-0

Cheung, F. M., Cheung, S. F., Zhang, J., Leung, K., Leong, F., \& Huiyeh, K. (2008). Relevance of openness as a personality dimension in Chinese culture: Aspects of its cultural relevance. Journal of Cross-Cultural Psychology, 39(1), 81-108. doi: 10.1177/0022022107311968

Cheung, F., Fan, W., \& To, C. (2008). The Chinese Personality Assessment Inventory as a culturally relevant personality measure in applied settings. Social and Personality Psychology Compass, 2(1), 74-89. doi: 10.1111/j.1751-9004.2007.00045.x

Cheung, G. W., \& Rensvold, R. B. (2002). Evaluating goodness-of-fit indexes for testing measurement invariance. Structural Equation Modeling, 9(2), 233-255. doi: 10.1207/S15328007SEM0902_5

Cole, D., \& Espinoza, A. (2008). Examining the academic success of Latino students in science technology engineering and mathematics (STEM) majors. Journal of College Student Development, 49(4), 285-300. doi: 10.1353/csd.0.0018

Connelly, B. S., Ones, D. S., Davies, S. E., \& Birkland, A. (2014). Opening up openness: A theoretical sort following critical incidents methodology and a meta-analytic investigation of the trait family measures. Journal of Personality Assessment, 96(1), 17-28. doi: 10.1080/00223891.2013.809355

Cooper, A., Gomez, R., \& Aucote, H. (2007). The behavioural inhibition system and behavioural approach system (BIS/BAS) scales: Measurement and structural invariance across adults and adolescents. Personality and Individual Differences, 43(2), 295-305. doi: 10.1016/j.paid.2006.11.023

Costa Jr, P. T., Terracciano, A., \& McCrae, R. R. (2001). Gender differences in personality traits across cultures: robust and surprising findings. Journal of Personality and Social Psychology, 81(2), 322-331. doi: 10.1037/0022-3514.81.2.322

De Raad, B., \& Schouwenburg, H. C. (1996). Personality in learning and education: A review. European Journal of Personality, 10(5), 303-336. doi: 10.1002/(SICI)1099-0984(199612)10:5<303::AIDPER262>3.0.CO;2-2

DeYoung, C. G., Peterson, J. B., \& Higgins, D. M. (2005). Sources of openness/intellect: Cognitive and neuropsychological correlates of the fifth factor of personality. Journal of Personality, 73(4), 825-858. doi: 10.1111/j.1467-6494.2005.00330.x

Dimitrov, D.M. (2010). Testing for factorial invariance in the context of construct validation. Measurement and Evaluation in Counseling and Development, 43(2) 121-149. doi: 10.1177/0748175610373459

Donnellan, M.B., Conger, R.D., \& Burzette, R.G. (2007). Personality development from late adolescence to young adulthood: Differential stability, normative maturity, and evidence for the maturity-stability hypothesis. Journal of Personality, 75(2), 237-263. doi: 10.1111/j.1467-6494.2007.00438.x

Duckworth, A. L., \& Seligman, M. E. P. (2005). Self-Discipline outdoes iq in predicting academic performance of adolescents. Psychological Science, 16(12), 939-944. Retrieved from https://www.jstor.org/stable/pdf/40064361.pdf

Dumfart, B., \& Neubauer, A. C. (2016). Conscientiousness is the most powerful noncognitive predictor of school achievement in adolescents. Journal of Individual Differences, 37(1), 8-15. doi: 10.1027/16140001/a000182

Durbin, C. E., Hicks, B. M., Blonigen, D. M., Johnson, W., Iacono, W. G., \& McGue, M. (2016). Personality trait change across late childhood to young adulthood: Evidence for nonlinearity and sex differences in change. European Journal of Personality, 30(1), 31-44. doi: 10.1002/per.2013

Eccles, J. (2011). Gendered educational and occupational choices: Applying the Eccles et al. model of achievement-related choices. International Journal of Behavioral Development, 35(3), 195-201. doi: 10.1177/0165025411398185

Fadjukoff, P., Feldt, T., Kokko, K., \& Pulkkinen, L. (2019). Identity status change within personal style clusters: a longitudinal perspective from early adulthood to midlife. Identity, 19(1), 1-17. doi: 10.1080/15283488.2019.1566066

Falk, A., \& Hermle, J. (2018). Relationship of gender differences in preferences to economic development and gender equality (IZA Discussion Papers, No. 12059). Institute of Labor Economics (IZA), Bonn. Retrieved from http://hdl.handle.net/10419/193353

Figueredo, A. J., Sefcek, J. A., \& Jones, D. N. (2006). The ideal romantic partner personality. Personality and Individual Differences, 41(3), 431-441. doi: 10.1016/j.paid.2006.02.004 
Fischer, A. H., \& Manstead, A. S. R. (2000). The relation between gender and emotion in different cultures. In A. H. Fischer (Ed.), Studies in emotion and social interaction. Second series. Gender and emotion: Social psychological perspectives (pp. 71-94). Cambridge University Press. doi: 10.1017/CBO9780511628191.005

Funder, D. C. (2001). Personality. Annual Review of Psychology, 52, 197-221. Retrieved from https://intranet.newriver.edu/images/stories/library/Stennett_Psychology_Articles/Personality.pdf

Gasser, C. E., Larson, L. M., \& Borgen, F.H. (2007). Concurrent validity of the 2005 Strong Interest Inventory: An examination of gender and major field of study. Journal of Career Assessment, 15(1), 23-43. Retrieved from http://citeseerx.ist.psu.edu/viewdoc/download?doi=10.1.1.908.2140\&rep=rep1\&type=pdf

Guimond, S. (2008). Psychological similarities and differences between women and men across cultures. Social and Personality Psychology Compass, 2(1), 494-510. doi: 10.1111/j.1751-9004.2007.00036.x

Heckman, J. J., Stixrud, J., \& Urzua, S. (2006). The effects of cognitive and non-cognitive abilities on labor market outcomes and social behavior. Journal of Labor Economics, 24(3), 411-482. Retrieved from https://www.nber.org/papers/w12006.pdf

Hu, L. T., \& Bentler, P. M. (1998). Fit indices in covariance structure modeling: Sensitivity to underparameterized model misspecification. Psychological Methods, 3(4), 424-453. Retrieved from https://pdfs.semanticscholar.org/a92c/9726361d9c1d165dbf2ea781b6c48363a816.pdfRelated

Hu, L. T., \& Bentler, P. M. (1999). Cutoff criteria for fit indexes in covariance structure analysis: Conventional criteria versus new alternatives. Structural Equation Modeling, 6(1), 1-55. doi: 10.1080/10705519909540118

John, O. P., \& Srivastava, S. (1999). The Big Five trait taxonomy: History, measurement, and theoretical perspectives. In L. A. Pervin \& O. P. John (Eds.), Handbook of personality: Theory and research (2nd ed., pp. 102-138). New York, NY: Guilford Press.

John, O. P., Neumann, L. P., \& Soto, C. J. (2008). Paradigm shift to the integrative Big-Five trait taxonomy: History, measurement, and conceptual issues. In O. P. John, R. W. Robins, \& L. A. Pervin (Eds.), Handbook of personality: Theory and research (3rd ed., pp. 114-158). New York, NY: Guilford.

Johnson, J. G., Cohen, P., Brown, J., Smailes, E. M., \& Bernstein, D. P. (1999). Childhood maltreatment increases risk for personality disorders during early adulthood. Archives of General Psychiatry, 56(7), 600-606. doi: 10.1001/archpsyc.56.7.600

Josephs, R. A., Markus, H. R., \& Tafarodi, R. W. (1992). Gender and self-esteem. Journal of Personality and Social Psychology, 63(3), 391-402. Retrieved from https://www.researchgate.net/profile/Robert_Josephs/publication/21751337_Gender_and_SelfEsteem/links/0912f5098177bd1614000000.pdf

Judge, T. A., \& Ilies, R. (2002). Relationship of personality to performance motivation: A meta-analytic review. Journal of applied psychology, 87(4), 797-807. doi: 10.1037//0021-9010.87.4.797

Judge, T. A., Erez, A., Bono, J. E., \& Thoresen, C. J. (2002). Are measures of self-esteem, neuroticism, locus of control, and generalized self-efficacy indicators of a common core construct? Journal of Personality and Social Psychology, 83(3), 693-710. doi: 10.1037//0022-3514.83.3.693

Kajonius, P. J., \& Johnson, J. (2018). Sex differences in 30 facets of the five-factor model of personality in the large public $(\mathrm{N}=320,128)$. Personality and Individual Differences, 129(July), 126-130. doi: 10.1016/j.paid.2018.03.026

Klein, H. J., \& Lee, S. (2006). The effects of personality on learning: The mediating role of goal setting. Human Performance, 19(1), 43-66. doi: 10.1207/s15327043hup1901_3

Klimstra, T. A., Luyckx, K., Branje, S., Teppers, E., Goossens, L., \& Meeus, W. H. (2013). Personality traits, interpersonal identity, and relationship stability: Longitudinal linkages in late adolescence and young adulthood. Journal of Youth and Adolescence, 42(11), 1661-1673. doi: 10.1007/s10964-012-9862-8

Kline, R. B. (2011). Principles and practice of structural equation modeling. New York, NY: The Guilford Press.

Korkmaz, M., Somer, O., \& Gungor, D. (2013). Measurement equivalence across gender with mean and covariance structure of five factor personality inventory for adolescent sample. Education and Science, 38(170). 121-134. Retrieved from http://egitimvebilim.ted.org.tr/index.php/EB/article/view/1532/550

Langen, A. V., \& Dekkers, H. (2005). Cross-national differences in participating in tertiary science, technology, engineering and mathematics education. Comparative Education, 41(3), 329-350. doi: $10.1080 / 03050060500211708$

Legewie, J., \& DiPrete, T. A. (2014). The high school environment and the gender gap in science and engineering. Sociology of Education, 87(4), 259-280. doi: 10.1177/0038040714547770

Lippa, R. A. (2010). Gender differences in personality and interests: When, where, and why? Social and Personality Psychology Compass, 4(11), 1098-1110. doi: 10.1111/j.1751-9004.2010.00320.x 
Lounsbury, J. W., Sundstrom, E., Loveland, J. M., \& Gibson, L. W. (2003). Intelligence, "Big Five" personality traits, and work drive as predictors of course grade. Personality and Individual Differences, 35(6), 1231-1239. Retrieved from http://citeseerx.ist.psu.edu/viewdoc/download?doi=10.1.1.936.3275\&rep=rep1\&type=pdf

Low, K., \& Rounds, J. (2007). Interest change and continuity from early adolescence to middle adulthood. International Journal for Educational and Vocational Guidance, 7(1), 23-36. doi: 10.1007/s10775-0069110-4

Lynn, R. (1993). Sex differences in competitiveness and the valuation of money in twenty countries. Journal of Social Psychology, 133(4), 507-511.

Manders, W. A., Scholte, R. H., Janssens, J. M., \& De Bruyn, E. E. (2006). Adolescent personality, problem behaviour and the quality of the parent-adolescent relationship. European Journal of Personality, 20(3), 237-254. doi: 10.1002/per.574

Matthews, G., Zeidner, M., \& Roberts, R. D. (2006). Models of personality and affect for education: A review and synthesis. In P. A. Alexander \& P. H. Winne (Eds.), Handbook of educational psychology (2nd ed., pp. 163-186). Mahwah, NJ: Erlbaum.

McAdams, D. P., \& Pals, J. L. (2006). A new Big Five: fundamental principles for an integrative science of personality. American Psychologist, 61(3), 204-217. Retrieved from http://people.wku.edu/richard.miller/new\%20big\%20five.pdf

McCrae, R. R., \& Costa, P. T., Jr. (1997). Conceptions and correlates of openness to experience. In R. Hogan, J. A. Johnson, \& S. R. Briggs (Eds.), Handbook of personality psychology (pp. 825-847). Academic Press. doi: 10.1016/B978-012134645-4/50032-9

McCrae, R. R., Terracciano, A., \& Pro, P. P. C. (2005). Personality profiles of cultures: Aggregate personality traits. Journal of Personality and Social Psychology, 89(3), 407-425. doi: 10.1037/0022-3514.89.3.407

McCrae, R. R., Yik, M. S., Trapnell, P. D., Bond, M. H., \& Paulhus, D. L. (1998). Interpreting personality profiles across cultures: Bilingual, acculturation, and peer rating studies of Chinese undergraduates. Journal of Personality and Social Psychology, 74(4), 1041-1055. doi: 10.1037/0022-3514.74.4.1041

Milfont, T. L., \& Fischer, R. (2010). Testing measurement invariance across groups: Applications in crosscultural research. International Journal of psychological research, 3(1), 111-130. Retrieved from http://45.5.172.45/bitstream/10819/6503/1/Testing_Measurement_Invariance_Milfont_2010.pdf

Morizot, J. (2014). Construct validity of adolescents' self-reported big five personality traits: Importance of conceptual breadth and initial validation of a short measure. Assessment, 21(5), 580-606. doi: $10.1177 / 1073191114524015$

Morsunbul, U. (2014). The validity and reliability study of the Turkish version of quick big five personality test. Dusunen Adam The Journal of Psychiatry and Neurological Sciences, 27(4), 316-322. doi: 10.5350/DAJPN2014270405

Mueller, G., \& Plug, E. (2006). Estimating the effect of personality on male and female earnings. Industrial and Labor Relations Review, 60(1), 3-22. Retrieved from http://www.jstor.org/stable/25067572

Nguyen, N. T., Allen, L. C., \& Fraccastoro, K. (2005). Personality predicts academic performance: Exploring the moderating role of gender. Journal of Higher Education Policy and Management, 27(1), 105-117. doi: 10.1080/13600800500046313

Noftle, E. E., \& Robins, R. W. (2007). Personality predictors of academic outcomes: Big five correlates of GPA and SAT scores. Journal of Personality and Social Psychology, 93(1), 116-130. doi: 10.1037/00223514.93.1.116

O’Connor, M. C., \& Paunonen, S. V. (2007). Big five personality predictors of post-secondary academic performance. Personality and Individual Differences, 43(5), 971-990. doi: 10.1016/j.paid.2007.03.017

Ock, J., McAbee, S. T., Mulfinger, E., \& Oswald, F. L. (2020). The practical effects of measurement invariance: gender invariance in two big five personality measures. Assessment, 27(4), 657-674. doi: 10.1177/1073191119885018

Paunonen, S. V., \& Ashton, M. C. (2001). Big five factors and facets and the prediction of behavior. Journal of Personality and Social Psychology, 81(3), 524-539. doi: 10.1037/0022-3514.81.3.524

Poropat, A. E. (2009). A meta-analysis of the five-factor model of personality and academic performance. Psychological Bulletin, 135(2), 322-338. doi: 10.1037/a0014996

Poropat, A. E. (2011). The Eysenckian personality factors and their correlations with academic performance. British Journal of Educational Psychology, 81(1), 41-58. doi: 10.1348/000709910X497671

Poropat, A. E. (2014). Other-rated personality and academic performance: Evidence and implications. Learning and Individual Differences, 34, 24-32. doi: 10.1016/j.lindif.2014.05.013

Putnick, D. L., \& Bornstein, M. H. (2016). Measurement invariance conventions and reporting: The state of the art and future directions for psychological research. Developmental Review, 41, 71-90. doi: 10.1016/j.dr.2016.06.004 
Rindermann, H., \& Neubauer, A. (2001). The influence of personality on three aspects of cognitive performance: Processing speed, intelligence and school performance. Personality and Individual Differences, 30(5), 829842. Retrieved from https://pdfs.semanticscholar.org/e468/6271719ef3a12ffc1e3db46bb705cf2195a6.pdf

Roberts, B. W., Kuncel, N., Shiner, R. N., Caspi, A., \& Goldberg, L. R. (2007). The power of personality: The comparative validity of personality traits, socio-economic status, and cognitive ability for predicting important life outcomes. Perspectives in Psychological Science, 2(4), 313-345. doi: 10.1111/j.17456916.2007.00047.x

Roberts, B. W., Walton, K. E., \& Viechtbauer, W. (2006). Patterns of mean-level change in personality traits across the life course: a meta-analysis of longitudinal studies. Psychological Bulletin, 132(1), 1-25. doi: 10.1037/0033-2909.132.1.1

Roets, A., \& Van Hiel, A. (2011). Item selection and validation of a brief, 15-item version of the need for closure scale. Personality and Individual Differences, 50(1), 90-94. doi: 10.1016/j.paid.2010.09.004

Rollock, D., \& Lui, P. P. (2016). Measurement invariance and the five-factor model of personality: Asian international and Euro American cultural groups. Assessment, 23(5), 571-587. doi: $10.1177 / 1073191115590854$

Samuel, D. B., South, S. C., \& Griffin, S. A. (2015). Factorial invariance of the five-factor model rating form across gender. Assessment, 22(1), 65-75. doi: 10.1177/1073191114536772

Sass, D. A. (2011). Testing measurement invariance and comparing latent factor means within a confirmatory factor analysis framework. Journal of Psychoeducational Assessment, 29(4), 347-363. doi: $10.1177 / 0734282911406661$

Saucier, G., \& Goldberg, L. R. (1996). The language of personality: Lexical perspectives on the five- factor model. In J. S. Wiggins. (Ed.), The five-factor model of personality: Theoretical Perspective (pp. 2150). New York, NY; Guilford.

Schmitt, D. P., Long, A. E., McPhearson, A., O’Brien, K., Remmert, B., \& Shah, S. H. (2017). Personality and gender differences in global perspective. International Journal of Psychology, 52(1), 45-56. doi: 10.1002/ijop. 12265

Schmitt, D. P., Realo, A., Voracek, M., \& Allik, J. (2008). Why can't a man be more like a woman? Sex differences in Big Five personality traits across 55 cultures. Journal of Personality and Social Psychology, 94(1), 168-182. doi: 10.1037/0022-3514.94.1.168

Shiner, R. L., Allen, T. A., \& Masten, A. S. (2017). Adversity in adolescence predicts personality trait change from childhood to adulthood. Journal of Research in Personality, 67, 171-182. doi: 10.1016/j.jrp.2016.10.002

Soto, C. J. (2016). The little six personality dimensions from early childhood to early adulthood: Mean-level age and gender differences in parents' reports. Journal of Personality, 84(4), 409-422. doi: 10.1111/jopy. 12168

Tabachnick, B.G., \& Fidell, L.S. (2001). Using multivariate statistics (4th ed.). Needham Heights, MA: Allyn \& Bacon.

Triandis, H. C., \& Suh, E. M. (2002). Cultural influences on personality. Annual Review of Psychology, 53(1), 133-160. doi: 10.1146/annurev.psych.53.100901.135200

Van de Schoot, R., Lugtig, P., \& Hox, J. (2012). A checklist for testing measurement invariance. European Journal of Developmental Psychology, 9(4), 486-492. doi: 10.1080/17405629.2012.686740

Vandenberg, R. J. (2002). Toward a further understanding of and improvement in measurement invariance methods and procedures. Organizational Research Methods, 5(2), 139-158. doi: $10.1177 / 1094428102005002001$

Vandenberg, R. J., \& Lance, C. E. (2000). A review and synthesis of the measurement invariance literature: Suggestions, practices, and recommendations for organizational research. Organizational research methods, 3(1), 4-70. doi: 10.1177/109442810031002

Vermults, A. A., \& Gerris, J. R. M. (2005). QBF: Quick Big Five persoonlijkheidstest handleiding [Quick Big Five personality test manual]. Leeuwarden, the Netherlands: LDC Publications.

Wang, M. T., \& Degol, J. L. (2017). Gender gap in science, technology, engineering, and mathematics (STEM): Current knowledge, implications for practice, policy, and future directions. Educational Psychology Review, 29(1), 119-140. doi: 10.1007/s10648-015-9355-x

Willingham, W. W., Pollack, J. M., \& Lewis, C. (2002). Grades and test scores: Accounting for observed differences. Journal of Educational Measurement, 39(1), 1-37. Retrieved from https://www.jstor.org/stable/1435104?seq=1\&cid=pdf-reference\#references_tab_contents 


\section{Hızlı Büyük Beşli Kişilik Testi: Cinsiyete Göre Ölçme Değişmezliğinin İncelenmesi}

\section{Giriş}

Kişilik ölçümünde yaygın olarak kullanılan kavramsallaştırma Beş Faktör Modelidir. Bu model kişiliği beş özellik alanına göre organize eder. Araştırmacılar Beş Faktör Kişilik Modeli'nin neredeyse evrensel düzeyde temsiliyeti üzerinde büyük ölçüde uzlaşmaya varmış durumdadır (John, Neumann \& Soto, 2008; Korkmaz, Somer \& Gungor, 2013; McCrae, Terracciano \& Pro, 2005).

Beş Faktör Modeli'nin kuramsal temelleri sözcük (lexical) hipotezi ile oluşturulmuştur. Bu hipoteze göre; insanların kişilik özelliği olarak en çok öne çıkan özellikleri önünde sonunda dillerinin bir parçası olur ve kullandıkları dilde de kendilerini gösterir. Bu hipotezden yola çıkılarak kişilik özelliklerini dillerdeki betimleyici sıfatlara bakarak belirlemek mümkün görülmüştür. Başta İngilizce olmak üzere kişiliğin göstergeleri olabilecek sıfatlar belirlenmiş sonra da başka dillerde faktör analitik çalışmalarla Beş Faktör Modeli'ne dayalı ölçekler geliştirmek ve geçerliğini incelemek mümkün olmuştur (Saucier \& Goldberg, 1996). Bunlardan biri de Büyük Beşli'dir. Büyük Beşli boyutları uyumluluk, sorumluluk, duygusal denge, dışadönüklük ve deneyime açıklık olarak belirlenmiştir.

Kişilik gelişimi üzerine yapılan çoğu araştırma erken yetişkinlik dönemine odaklanmıştır. Bunun nedeni, kişilik gelişiminin beyin gelişimine bağlı olarak 25 hatta 28 yaşına kadar devam etmesidir. Bir diğer nedeni de yetişkinliğe geçişteki 18 ile 30 yaş arasının samimiyet, girişimcilik, sosyal ilgiler, kimlik, iş ve ebeveynlik açısından önemli bir gelişim evresi olmasıdır (Arnett, 2000). Araştırmalar erken yetişkinlik döneminde ilgi alanlarının kristalize olduğunu ve dengelediğini ayrıca kariyer hedeflerinin ve ileriye dönük beklentilerinin kişisel ve çevresel özelliklere uyum sağlama açısından daha gerçekçi hale geldiğini göstermiştir (Low \& Rounds, 2007).

Kadınlar ve erkekler arasındaki psikolojik farklılıklar her zaman incelenen bir konu olmuştur (Kajonius \& Johnson, 2018). Peki, kişilikteki cinsiyet farklılığını incelemek neden önemlidir? Öncelikle kişilik üzerindeki cinsiyet farklılıkları kültürler arası tüm araştırmalarda gözlenmiştir. Bu nedenle evrensel bir husustur. Bir diğeri, kişilikteki cinsiyet farklılıklarının yaşam süresi boyunca istikrar göstermesidir (Donnellan, Conger, \& Burzette, 2007). Bu da bize bireylerin gelecekteki seçimlerinin eğilimi ve bu seçimler sonucunda karşı karşıya kalacakları durumlar hakkında bilgi verir. Ayrıca mesleki, eğitsel, eş seçme, çatışma, ilişki düzenleme gibi sosyal pek çok seçimler kişilikle ilişkilidir (Berings, De Fruyt, \& Bouwen, 2004; Bono, Boles, Judge, \& Lauver, 2002; Figueredo, Sefcek, \& Jones, 2006; Gasser, Larson, \& Borgen, 2007). Bunun yanında meta-analiz çalışmalar da psikolojik değişkenler üzerindeki cinsiyet farklılıklarının incelenen yapıya göre değişkenlik gösterdiğini ortaya çıkarmaktadır. Böylece, kişilik özellikleri gibi psikolojik etmenlerin incelenmesi yoluyla bireylerin özellikle de kadınların eğitim, beceri ve mesleki açıdan gelişimlerinin izlenmesi ve iyileştirilebilmesi mümkün olabilir.

Kişilik ve kişiliğin sosyal ve ekonomik yapılarla ilişkileri her daim canlı bir araştırma konusu olmuştur (Funder, 2001). Bir işte veya akademik faaliyetlerde performans gösterme isteği ve performansta devaml1l1k zihinsel yetenekten ziyade (Heckman, Stixrud, \& Urzua, 2006, Willingham, Pollack, \& Lewis, 2002) kişilik faktörleri tarafından daha belirleyici bulunmuştur (Judge \& Ilies, 2002). Literatürde bazı çalışmalar zihinsel olmayan becerilerin çocukların ve ergenlerin okul performanslarında önemli rol oynadığını göstermiştir (Duckworth \& Seligman, 2005). Açıkçası, öğrencilerin akademik performanslarını incelemek oldukça önemlidir, çünkü toplumlar ve bireyler tarafından eğitime önemli yatırımlar yapılmakta, bu da eğitim performansına verilen yüksek değeri göstermektedir (Poropat, 2009). Akademik performansla Büyük Beşli kişilik faktörleri arasında güçlü ilişkilerin olması da eğitsel açıdan kişilik özelliklerine daha fazla eğilmemiz gerektiğine işaret etmektedir.

Farklı kültürler ve örneklemlerle yapılan ampirik çalışmalarla Büyük Beşli kişilik faktör yapısının sağlamlığı desteklenmiştir. Ancak bir psikolojik yapının karşılaştırma grupları arasında farklılık veya 
benzerlikleri yorumlanmak isteniliyorsa öncelikle ölçme değişmezliği yoluyla psikolojik yapının değişmezliğinin test edilmesi gerekir. Bu nedenle hemen her disiplinde (psikoloji, sağlık, ekonomi, eğitim, sosyoloji vb.) yaygın olarak kullanılan Büyük Beşli faktör yapısının daha ileri geçerlik analizleri ile desteklendiği araştırmalara ihtiyaç vardır. Büyük Beşli için karşılaştırma gruplarında ancak skaler ölçme değişmezliği sağlanabilirse alt gruplardan elde edilen puanlar (veya gizil ortalamalar) arasında anlamlı karşılaştırmalar yapılabilmesi mümkün olur (Ock, McAbee, Mulfinger, \& Oswald, 2019; Sass, 2011). Aksi takdirde ortaya çıkan farklılıkların gerçekten gruplar arasındaki farklılığa mı yoksa psikolojik yapının eşdeğer olmayışından kaynaklı bir duruma mı atfedilip atfedilemeyeceği belirlenemez. Bu durumda psikolojik yapının hem geçerliği hem de genellenebilirliği sorunlu hale gelir.

Türkiye'de Büyük Beşli kuramına göre yapılandırılan ölçekler olmasına rağmen sadece Korkmaz ve diğerleri (2013) geliştirdikleri 200 maddelik ölçek üzerinden lisede öğrenim gören ergen gruplarında cinsiyete göre ölçme değişmezliğini incelemişlerdir. Ancak bu konuda daha fazla araştırmalara ihtiyaç vardır. Yaşam dönemleri boyunca kişilik özelliklerinin gelişimini anlamak kuramsal ve pratik sonuçlar içerir (Roberts, Kuncel, Shiner, Caspi, \& Goldberg, 2007). Özellikle görece daha kısa kendini rapor etme araçlarından elde edilen puanların ileri çalışmalarla geçerliğinin incelenmesi önem arz etmektedir. Bu nedenle, bu çalışmada pek çok disiplinde kullanılan Hızlı Büyük Beşli faktörlerinin Türk erken yetişkin örnekleminde geçerliği ve cinsiyete göre ölçme değişmezliğinin test edilmesi amaçlanmıştır. İkinci amaç doğrultusunda Hızlı Büyük Beşli faktörlerinin cinsiyete göre yapısal, metrik, skaler ve katı ölçme değişmezliği araştırılmıştır.

\section{Yöntem}

Bu araştırmaya yaşları 17-32 arasında değişen İç Anadolu Bölgesi'nde öğrenim gören 1114 üniversite öğrencisi katılmıştır. Katılımcıların 659'ü kadın (\%59) ve 455'i erkek (\%41) olduğunu beyan etmiştir. Kişilik özelliklerini ölçmek için Vermulst ve Gerris (2005) tarafından geliştirilen Hızlı Büyük Beşli Kişilik ölçeği kullanılmıştır. Ölçek 30 maddeden oluşmaktadır. Her kişilik özelliği altı maddeyle ölçülmektedir. Alt ölçekler için Cronbach Alfa değerleri .73 ile .88 arasında değişmektedir. Ölçek Morsunbul (2014) tarafından Türk kültürüne uyarlanmıştır. Uyarlama çalışmasında alt ölçeklerin Cronbach Alfa katsayıları .71 ile .81 arasında değiştiği rapor edilmiştir. Doğrulayıcı faktör analizi (DFA) ve çok gruplu DFA analizleri LISREL9.2 programı ile gerçekleştirilmiştir.

$\mathrm{Bu}$ çalışmada ölçme değişmezliği çoklu grup doğrulayıcı faktör analiziyle test edilmiştir. Ölçme değişmezliğinin test edilmesinde aşamalı olarak devam eden süreçler vardır. İlk aşamada karşılaştırma grupları için ayrı ayrı DFA yapılarak ölçme modeli test edilir. Eğer model uyumu sağlanırsa, ikinci aşamada söz konusu gruplar için yapısal değişmezlik, metrik değişmezlik, faktör kovaryansları (skaler) değişmezliği ve hata varyansları (katı) değişmezliği sınanır (Dimitrov, 2010). Her bir model, bir önceki model ile karşılaştırılır. Bu iç içe yuvalanmış modelleri karşılaştırmak için ki-kare fark testi kullanılır (Brown, 2006; Dimitrov, 2010; Tabachnick \& Fidell, 2001). Her bir model için manidar bir farkın olmaması, ölçme değişmezliğin sağlandığını gösterir.

Ki-kare testinin örneklem büyüklüğüne duyarlı olması nedeniyle iç içe yuvalanmış model karşılaştırmalarında daha dirençli bir gösterge olan CFI fark değerlerinin kullanılması önerilmektedir (Cheung \& Rensvold, 2002). Ölçme değişmezliğin sağlanamadığı durumlarda kısmi değişmezlik incelenmelidir. Kısmi değişmezlik sürecinde en büyük modifikasyon üreten parametreler belirlenir. $\mathrm{Bu}$ parametreler tek tek serbest bırakılarak değişmezliğin sağlanıp sağlanmadığı incelenir.

\section{Sonuç ve Tartışma}

Genel olarak, uyum indekslerinin çoğu, Hızlı Büyük Beşli'nin tüm örneklem ve cinsiyet grupları için verilere yeterli uyum gösterdiğini ortaya çıkarmıştır. Ancak, RMSEA ve $\chi^{2} / s d$ değerlerinde bir miktar model uyumsuzluğu gözlenmiştir. Ki-kare istatistiğinin model büyüklügüne ve örneklem büyüklügüne duyarlı olmasından dolayı (Putnick \& Bornstein, 2016), ki-kareye bağlı değerlerde model uyumsuzluğunun izlenmesi şaşırtıcı değildir. Bu bulgular, literatürdeki kişilik özelliklerine ilişkin 
bulgular ile uyumludur. Örneğin, Beauducel ve Wittmann (2005) DFA uyum indekslerinin simülasyon çalışmalarındaki performansını incelemişlerdir. Araştırmaları sonucunda araştırmacılar RMSEA ve $\chi^{2} / s d$ değerleri için uyumsuzluk gösterme eğilimi olduğunu belirtmişlerdir.

Bulgular, cinsiyete göre tam yapısal, kısmi metrik ve skaler değişmezlik sağlandığını göstermiştir. Yapısal değişmezliğin sağlanmış olması Hızlı Büyük Beş ölçeğinin kadın ve erkekler arasında karşılaştırılabilir faktör yapısına sahip olduğunu belirtir. Bir sonraki aşamada, tam metrik değişmezliği incelenmiştir. Ancak tam metrik değişmezliğin sağlanmadığı ortaya çıkmıştır. Bu nedenle, kısmı değişmezlik incelenmiştir. En büyük modifikasyon indeksi üreten madde deneyime açıklık faktörü altındaki "hayal gücü geniş" maddesi olarak belirlenmiştir. Bu maddeye ilişkin faktör yükleri serbest bırakılarak tekrar metrik değişmezlik incelendiğinde yine değişmezliğin sağlanamadığ 1 görülmüsstür. Devam eden süreçte en büyük modifikasyon indeksi üreten bir sonraki madde olan "meraklı" maddesinin faktör yükleri gruplar arasında serbest bırakılmışıı. Çoklu grup DFA bulguları, bu iki madde serbest bırakıldığında kısmi metrik değişmezliğin sağlandığını göstermiştir. Bu iki maddeye ilişkin parametreler serbest bırakıldığında skaler değişmezliğin de sağlandığı gözlenmiştir.

Cinsiyet grupları arasında faktör yük değerleri incelendiğinde erkekler Deneyime Açıklık boyutundaki her iki madde üzerinde de ("hayal gücü geniş" ve "meraklı") daha yüksek değerler elde etmişlerdir. Bu bulgu, erkeklerde söz konusu bu iki maddenin gizil yapı ile daha güçlü bir şekilde ilişkili olduğunu ifade etmektedir. Başka bir deyişle, bu iki maddenin erkekler ve kadınlar için farklı bir anlamı mevcuttur. Türkiye'nin ataerkil kültürel bağlamı göz önüne alındığında bu bulgu anlaşılabilirdir. Nitekim, bu toplumda erkekler doğdukları andan itibaren çevrelerini keşfetmeye ve bağımsız olmaya teşvik edilirken bilakis kadınların davranışları yakından kontrol edilip sürekli takip edilmektedir. Cinsiyet rolleri kadınlar için kurallara uyan bir yaşam tarzını sosyal hayatlarına işlemektedir. $\mathrm{Bu}$ nedenle, kızlar, özellikle "cinsel koruma" adı altında, çevrenin keşfi ve yeni yaşam becerileri elde etme fırsatlarını değerlendirme yönünde sürekli bir engelleme ile karşılaşırken, erkelerin yeni deneyimler konusundaki merakları cesaretlendirilir ve övülürler. Kısacası, erkeklere ve kadınlara yeni deneyimler elde etme konusunda son derece farklı kurallar verilir. Bu nedenle deneyime açıklık boyutundaki bu iki maddenin cinsiyet gruplarında eşdeğer anlamları karşılamıyor oluşu anlaşı1ırdır.

Kısmi metrik değişmezlik sağlandıktan sonra skaler değişmezlik test edilmiştir. Bulgular, açıklık faktörü altındaki iki madde hariç diğer maddelerin, cinsiyet grupları arasında değişmez olduğunu göstermiştir. Bu bulgular, bir ergen örneği üzerinde Morizot (2014) tarafından yapılan çalışmanın bulgularıyla kısmen uyumludur. Morizot (2014) Büyük Beşli Kişilik Özellik Kısa Anketi’nde dört madde serbest bırakıldığında kısmi skaler değişmezliğin sağlandığını bildirmiştir. Bu dört maddeden ikisi, Açıklık boyutuyla ilişkiliydi ve metrik değişmezliğin sağlanamamasına neden olmuştu. Mevcut literatüre göre, Açıklık ile ilgili maddeler Büyük Beşli Modeli'nde en düşük uyuma sahip olarak ortaya çıkmaktadır (Rollock \& Lui, 2016). Öyle ki, özgün Çin Kişilik Değerlendirme Envanterinde Açıklık faktörü hiç ortaya çıkmamıştır (Cheung ve diğerleri, 2008). Bunun nedeni, Batı merkezli kişiliğin kavramsallaştırılması üzerine inşa edilen Büyük Beşli Modeli'nin daha kolektif Doğu kültürüne uymaması olarak belirtilmiştir (Cheung, Fan \& To, 2008). Triandis ve Suh (2002) Açıklık faktörünün, bireysel kültürlerde, daha kolay ortaya çıktığını belirtmişlerdir. Ayrıca, kişilik gibi tek bir psikolojik alanda bile kültürün farklı düzeylerde etkiye sahip olduğuna dair görüşler vardır (McAdams \& Pals, 2006). McCrae, Yik, Trapnell, Bond ve Paulhus (1998), Açıklık boyutunun çapraz dil eşdeğerliğinin oldukça sınırlı olduğunu, ancak bu sonucun şaşırtıcı olmadığını, çünkü ölçeğin ilgili alanlarının tutumsal yansımalarını ölçtüğü ve de tutumların kuşkusuz kültürel bağlamdan etkilendiğini belirtmişlerdir.

En üst düzeydeki ölçme değişmezliği katı değişmezliktir. Bu çalışmada katı değişmezlik test edilmiş ancak sağlanamamıştır. Literatürde katı değişmezliğin çok kısıtlı bir test olduğu belirtilmektedir, bu nedenle gruplar arasında gizil ortalamalar karşılaştırılırken katı değişmezliğin sağlanması zorunlu değildir (Brown, 2006).

Bu çalışma önemli sonuçlar içermektedir. İlk olarak, DFA bulguları, Hızlı Büyük Beşli'nin hem tüm örneklemde hem de kadın ve erkek katılımcılar için model veri uyumunun doğruladığını göstermiştir. Bu çalışmanın ikinci önemli sonucu, Hızlı Büyük Beşli ölçeğinin Türk erken yetişkin örnekleminde işlev gösterdiğinin ortaya konmasıdır. Ayrıca, Hızlı Büyük Beşli ölçeğinde erkekler ve kadınlar 
arasında tam yapısal, kısmi metrik ve skaler değişmezlik elde edilmiştir. Bu sonuç, iki madde dışarıda tutulmak suretiyle cinsiyet grupları arasında gizil değişken ortalamalarına ilişkin anlamlı karşılaştırmaların yapılabileceğini belirtmektedir. Unutmamak gerekir ki, ölçme değişmezliğinin sağlanamadığı maddeleri dikkate almadan grup karşılaştırmaları yapmak yanlı kararlara yol açabilecektir. Bu çalışma, mevcut kişilik araştırmalarına yeni geçerlik kanıtları eklemiştir. Gelecekteki çalışmalarda, farklı karşılaştırma grupları için geçerlik kanıtı araştırılabilir ve ölçme değişmezliği incelenebilir. 